\title{
EDITORS' REPORT FOR VOLUME 58
}

We are pleased to report the publication of this volume of Madroño by the California Botanical Society (CBS) in 2011. The journal continues to evolve as we get closer to the centennial year in 2013. Starting with the next volume, the CBS will introduce a "Point-of-View" section which will allow contributors to provide input on recent articles or air ideas related to western botany. We are hoping this will be a lively and informative forum. The Madrono page on the CSB web site is an up-to-date gateway for contributors, provides the link to the online submission page, and links to the eightyyear index. We continue to see an increase in the number of submissions and better turn around with reviewers.

The efforts of numerous individuals are critical to the continuing quality of the journal. Among these, our Noteworthy Collections editor, Dieter Wilken; Steve Timbrook who has long provided the volume Index and Table of Contents; Annielaurie Seifert at Allen Press; and the enthusiastic support of the CBS executive council. Finally, we are extremely grateful to our contributors who provide interesting and insightful manuscripts, and our volunteer reviewers who take time from their busy schedules to assess the quality of submitted work.
This year we received 43 new manuscripts and 39 were accepted for publication. Several manuscripts were also carried over from the previous year. The current volume includes 20 articles (including Notes), five new taxa, five Noteworthy Collections, and two Book Reviews. We appreciate the mix of submitted manuscripts across the spectrum of botanical sciences and anticipate continued submissions of novel and exciting work.

As Editors, we have enjoyed our interactions with contributors and reviewers this past year. In the coming year, we have a new Corresponding Editor, Matt Ritter who brings a fresh perspective and has already taken on many responsibilities with the journal. For the coming year we are focused with brining the journal up to date so that we start the Centennial year on time and with exciting contributions related to the Centennial celebration.

Tim Lowrey

Richard Whitkus December 2011 


\section{$2 \mathrm{BHL}$ Biodiversity Heritage Library}

Lowrey, Tim and Whitkus, Richard. 2011. "Editors' Report for Volume 58." Madroño; a West American journal of botany 58, 279-279.

https://doi.org/10.3120/0024-9637-58.4.279.

View This Item Online: https://www.biodiversitylibrary.org/item/185625

DOI: https://doi.org/10.3120/0024-9637-58.4.279

Permalink: https://www.biodiversitylibrary.org/partpdf/169160

\section{Holding Institution}

Smithsonian Libraries

\section{Sponsored by}

Biodiversity Heritage Library

\section{Copyright \& Reuse}

Copyright Status: In Copyright. Digitized with the permission of the rights holder License: http://creativecommons.org/licenses/by-nc/3.0/ Rights: https://www.biodiversitylibrary.org/permissions/

This document was created from content at the Biodiversity Heritage Library, the world's largest open access digital library for biodiversity literature and archives. Visit BHL at https://www.biodiversitylibrary.org. 